\title{
Influence of Human Resource Competence, Internal Control System, Participation in Budget Preparation, and Accounting Control on Performance Accountability of Local Government Agencies
}

\begin{abstract}
Gati Reditya Saputra ${ }^{1, *}$
${ }^{1}$ Department of Accounting, Faculty of Economics and Business, Universitas Muhammadiyah Yogyakarta, Indonesia ${ }^{*}$ Corresponding author. Email: gati.reditya@fe.umy.ac.id

ABSTRACT

This study aims to obtain empirical evidence on the influence of human resource competencies, internal control systems, participation in budget preparation, and accounting control on the performance accountability of government agencies. The data collection method in this study used questionnaires. Research questionnaires were given to regional apparatus work units in Sleman and Bantul Regencies. Sampling questionnaires employed purposive sampling. The questionnaires distributed were 92, with returned as many as 82 and processed as many as 72 questionnaires. The data collected were then processed utilizing multiple linear regression analysis. The results of this study showed that the internal control system and accounting control had a significant positive effect on the performance accountability of government agencies, while the competence of human resources and participation in budget preparation did not affect the performance accountability of government agencies.
\end{abstract}

Keywords: Competence of human resources, Internal control system, Participation in budget preparation, Accounting control, Performance accountability of government agencies

\section{INTRODUCTION}

The enactment of Law Number 32 of 2004 concerning regional government stipulates that "regional autonomy is the right, authority, and obligation of an autonomous region to regulate and manage its government affairs and the interests of the local community following statutory regulations." Local governments are given the authority and obligation to manage the region itself as a whole, which can reduce the work of the central government. Regional autonomy is also decentralization, which is the central government's authority over local governments, expected to positively impact following the wishes of the Indonesians (Pratolo, 2008).

Local governments can give authority to regulate and determine the amount of resource allocation according to the region's needs and capabilities with clear objectives and being responsible. Local governments are also encouraged to improve and utilize their potentials (Suryani, 2018). Thus, the authority and obligations of local governments in managing resources must be accounted for in an accountable and transparent manner.

Moreover, in Presidential Regulation number 29 of 2014, "performance accountability is the embodiment of the obligation of a government agency to account for the success/failure of implementing programs and activities that stakeholders have mandated to achieve the organization's mission measurably with performance targets set through agency performance reports, which the government compiled periodically." Thus, accountability is a must in the public sector to always emphasize responsibility not only to superiors but also to the community (Putra, 2018). In other words, accountability is the obligation of someone entrusted with managing a public resource and can be accountable to the whole community (Cahyani \& Utama, 2015). With the trust given by the community to local governments in managing public resources, local governments should be able to take responsibility for managing public resources and be able to provide information on the activities carried out. Providing information in government agencies is the fulfillment of the community's rights, namely the right to obtain correct information according to the performance of government agencies and the right to be responsible for the management of public resources in government agencies.

Based on the results of the monitoring and evaluation conducted by the Ministry of State Apparatus Empowerment and Bureaucratic Reform, performance accountability is still weak, and the accountability system of government agency performance (SAKIP) has not been implemented in a real and consistent manner, including:

1. Lack of commitment in prioritizing performance accountability. Performance accountability has not become a big concern, especially at the level of Ministries/Agencies/Local Governments.

2. Several laws and regulations on performance accountability are not aligned.

3. There are no strict sanctions on government agencies in implementing performance accountability. 
4. There is still a lack of socialization on policies regarding performance accountability in government agencies.

5. Limited capability of human resources regarding performance accountability in government agencies

6. The accountability system for the performance of government agencies is still not integrated with the national planning system and budgeting system.

Thus, to realize a performance that has good accountability, it can be supported by various factors such as human resources. Human resources are quite influential on a company or organization's performance since superior human resources can provide guarantees if the goals can be achieved as planned. Elizar \& Tanjung (2018) revealed that human resource competence is an ability that employees or workers must possess in carrying out their work so that with good competence, employees or workers can complete work according to the planned targets. Another supporting factor is the internal control system. This internal control system is needed in performance to maximize and encourage the resources of the organization or government. Internal control is also the processes carried out by employees and management in providing certainty in achieving its objectives in sections, such as reliable financial statements, as well as the implementation of effectiveness and efficiency in the operational activities of the organization by using laws and regulations that must be obeyed by all parties involved (Mamuaja, 2016).

In addition to the above factors, two other factors can affect performance accountability, comprising participation in budgeting and accounting control. Participation in budgeting influences individuals in decision-making to be evaluated and achieve budget targets to improve performance in government or organizations. Participation in budgeting is also an approach taken by managers to improve the performance of an organization's members (Nazaruddin \& Setyawan, 2012). The last factor is accounting control, which is a useful control to provide procedures and authority in government performance to reduce errors. Accounting controls are controls to prevent and reduce intentional or unintentional errors (Mikoshi, 2020).

Moreover, Cahyani \& Utama (2015) revealed that accounting control had a positive effect on the accountability of government agencies. This study is also the same as research by Zakiyudin (2015) and Pratama, Agustin, \& Taqwa (2019) that accounting control positively affected government agencies' accountability. Meanwhile, according to Anjarwati (2012), accounting control did not affect the performance accountability of government agencies. Besides, this research is the result of a compilation of previous studies conducted by several researchers, such as Anjarwati (2012), Widyatama, Novita, \& Diarespati (2017), and Arifin (2012). A study carried out by Anjarwati (2012) examined the effect of clarity on budget targets, accounting controls, and reporting systems on government accountability in Tegal City and the Pemalang Regency. In her test, the clarity of the budget and reporting system had a positive effect on the accountability of government agencies, while the accounting control variable did not affect the accountability of government agencies. In addition, the research of Widyatama et al. (2017) investigated the influence of the competence of the apparatus and the internal control system on the accountability of the village government of Sigi Regency. In their research, the competence of the apparatus did not affect government accountability, while the internal control system had a positive effect on government accountability. Moreover, Arifin (2012) scrutinized the effect of budget participation, accounting control, budget clarity, and reporting systems on local government accountability with organizational commitment as a moderating variable in the Pekalongan Regency. In that study, budget participation, accounting control, budget clarity, and reporting system had a positive effect on local government accountability, while budget participation, accounting control, budget clarity, and reporting system with organizational commitment as a moderating variable did not affect local government accountability.

Further, SAKIP uses an assessment with five indicators: performance planning, performance measurement, performance reporting, performance evaluation, and performance achievement. With this, this study can determine the influence of various factors that can affect accountability in local government. The difference between this study and previous studies is that the research sample was located in the regional apparatus work units (SKPD) of the Sleman Regency and Bantul Regency.

\section{LITERATURE REVIEW AND HYPOTHESIS DEVELOPMENT}

\subsection{Stewardship Theory}

Stewardship theory describes that managers are not motivated by individual goals but by organizational goals under their principles (Davis, 1997). Stewardship theory illustrates that a manager can behave, following common interests to achieve organizational goals; managers in organizations are more concerned with organizational goals than individual goals (Raharjo, 2007). With this theory, organizational goals can be achieved properly since all stakeholders work together to achieve organizational goals and can be held accountable for the results.

Through Stewardship theory, organizations can protect and maximize their wealth with performance so that efficiency will be maximized (Raharjo, 2007). This kind of behavior can benefit them in achieving their goals. This theory also assumes that the organization's success with public satisfaction contributes to organizational performance and maximum service.

\subsection{Government Performance Accountability}

Accountability is an obligation in conveying accountability and providing performance results that have been achieved, and notifying the actions of bodies, organizations, and individuals to parties who have the authority to take responsibility (Putri, 2015). Government accountability is an obligation to provide accountability and information on government performance or actions to the authorities (Darma, 2019). According to Triyulianto (2018), the government performance accountability system (SAKIP) is the responsibility of each apparatus, which has several indicators and methods of measuring, evaluating, and 
reporting the performance of activities in a comprehensive and integrated manner to fulfill organizational obligations in government and are responsible for success or failure on government tasks or programs. In addition, accountability is an obligation or responsibility for the performance results that have been achieved in the government following the initial objectives or not yet appropriate and is obliged to provide information to interested parties.

According to Presidential Regulation No. 29 of 2014, it states "The accountability system of government agency performance (SAKIP) is a systematic series of various activities, tools, and procedures designed to determine and measure, collecting data, classifying, summarizing, and reporting performance to government agencies in the framework of accountability and performance improvement of government agencies."

\subsection{Human Resources Competency}

In producing quality and good performance, the high competence of human resources is needed to run the existing system properly (Sunarmo et al., 2016). That way, high human resource competence will affect the performance of government agencies to be better and more qualified than low human resources. Hence, human resource competence can be of added value in government agencies. According to Putri (2015), competence is a combination of skills and abilities of a person needed in work and functions in managing work. Competence of human resources can also make it easier to carry out tasks and programs and can be a factor in achieving good governance in government (Irvan et al., 2017). With adequate skills and abilities, HR competencies can affect doing work and making work easier. Excellent HR can also complete their tasks and responsibilities more quickly and correctly within the specified time limit.

Based on previous studies, it can be concluded well that the application of high human resource competence is driven by various parties contained in the components of existing work units in the government, and it will be able to increase the success of performance in implementing tasks and programs in local government and can be accounted for to interested parties. Thus, with high competence, the performance of government employees will be better. From the description above, the first hypothesis is derived as follows:

H1: Human resource competence has a positive effect on the performance accountability of government agencies.

\subsection{Internal Control System}

The internal control system is used to maintain and direct the organization following the objectives that have been made (Kaltsum \& Rohman, 2012). That way, the internal control system can be used to determine the extent to which the performance made has been running as desired. The internal control system is also a process that can be influenced by management and employees in providing certainty regarding the achievements obtained objectively in its trusted implementation, efficiency, and effectiveness in the company's operational activities under applicable regulations and laws (Mamuaja, 2016). The internal control system can control a person in achieving success at work, which is following the targets to be achieved by the government organization and the company.

The internal control system can improve performance and achieve success in carrying out the tasks and programs that have been planned for the local government according to the target and can be accounted for by interested parties. With this description, the second hypothesis is derived as follows:

H2: The internal control system has a positive effect on the performance accountability of government agencies.

\subsection{Participation in Budget Preparation}

The budget is one of the important factors in the performance of the central or regional government since the budget is one of the crucial things that must always be there. At the stage of preparing the budget, it is very important because, at this stage, it can provide information about problems that will arise in the planning that has been made (Pratiwi, 2014). According to Aulad et al. (2018), participation in budgeting needs to use suggestions and aspirations from the stakeholders because the budget must be following the conditions in the field. Meanwhile, according to Ernis et al. (2017), concerning budgetary participation, the involvement of top-level managers, middle-level managers, and lower-level managers is needed in the budgeting process. Thus, participation in budgeting needs to use various parties within an organization to achieve the targets that have been made.

With this, participation in budgeting can increase the accountability of the performance of government agencies since all components from the top to the bottom level work together in preparing a good and correct budget. Thus, with the results of the description above, the third hypothesis is derived as follows:

H3: Participation in budgeting has a positive effect on the performance accountability of government agencies.

\subsection{Accounting Control}

Accounting control is a formal procedure or system that uses the information to change and maintain company activities with control as a process in company management to ensure that resources are used following the objectives or economically, efficiently, and effectively (Hidayattullah \& Herdjiono, 2015). Accounting control is also responsible for determining the direction in which the company or organization will run to follow the expected goals and minimize fraud in the government.

In addition, accounting controls are integral to planning and controlling efficiency and reducing deviations (Hari Setyawan, 2017). Accounting control can also provide convenience and means in controlling the work plan and reducing deviation risk. Besides, accounting control can improve performance success supported by reliable information and good procedures to produce organizational goals and targets as expected. According to the description above, the fourth hypothesis is derived as follows:

H4: Accounting control has a positive effect on the performance accountability of local government agencies. 


\section{METHODOLOGY}

This study examined various factors that could affect the implementation of performance accountability of government agencies in Sleman and Bantul Regencies. This study used the regional apparatus work units (SKPD) population in the regional government of Sleman Regency and Bantul Regency. The sample used in this study was taken from each regency totaling 50 samples.

The research data were primary and quantitative data obtained by asking questions in the form of a questionnaire to each SKPD. Several questions refer to the accountability of government agency performance, human resource competence, internal control system, budgeting participation, and accounting control.

The sampling technique in this study employed purposive sampling. Purposive sampling technique is a way to determine the sample following what is desired by the researcher, carried out at the regional apparatus work units (SKPD) of Sleman Regency and Bantul Regency, with the following criteria:

1. The sample of this research was employees who served as Head of SKPD, Secretary of SKPD, and Head of Division at SKPD of Sleman Regency and Bantul Regency, Special Region of Yogyakarta Province.

2. They had those positions for two years. This criterion was intended for respondents who already had a position of at least two years.

Moreover, multiple regression analysis was utilized in this study to analyze the effect of four independent variables $(\mathrm{X})$ on the variable $(\mathrm{Y})$. Researchers conducted testing using SPSS. Multiple regression equation is as follows:

$$
Y=a+\beta_{1} X_{1}+\beta_{2} X_{2}+\beta_{3} X_{3}+\varepsilon
$$

Information:

$\mathrm{Y}=$ Performance accountability of local government

agencies

$\mathrm{X}_{1}=$ Human resources competence

$\mathrm{X}_{2}=$ Internal control system

$\mathrm{X}_{3}=$ Participation in budget preparation

$\mathrm{X}_{4}=$ Accounting control

$\beta_{1}=$ Coefficient of human resources competence

$\beta_{2}=$ Coefficient of internal control system

$\beta_{3}=$ Coefficient of participation in budget preparation

$\beta_{4}=$ Coefficient of accounting control

$\mathrm{a}=$ Constanta

$\varepsilon=$ Error

\section{DISCUSSION}

This study aims to determine the role of human resource competencies, internal control systems, budgeting participation, and accounting control on local government agencies' performance accountability. The empirical testing results carried out on several hypotheses are explained as follows:
4.1. The Influence of Human Resource Competence on the Performance Accountability of Local Government Agencies

In the research results on the first hypothesis (H1), it can be seen that the competence of human resources did not affect the accountability of the performance of local government agencies, with a significance value of $0.089>$ alpha $(\alpha=$ $0.05)$. This test indicates that the competence of human resources in government organizations has not been able to increase performance accountability in local government agencies. The ineffectiveness of human resource competence on the accountability of the performance of local government agencies was based on the lack of apparatus in understanding government competence and knowledge of accountability regarding tasks and programs as planned. In local government, the competence of the apparatus is related to the knowledge, abilities, and skills in the main tasks. The government apparatus is the executor of the tasks and programs that have been planned so that each apparatus must carry out and complete tasks and programs following what has been planned and accounted for as well as possible. If the apparatus does not have good competence, the tasks and programs in government organizations may not run well and are difficult to account for.

\subsection{The Influence of the Internal Control System on the Performance Accountability of Local Government Agencies}

In the research results on the second hypothesis (H2), it can be seen that the internal control system had a positive effect on the performance accountability of government agencies, with a significance value of $0.00<$ alpha $(\alpha=0.05)$. This test shows that the higher the internal control system implemented by the regional apparatus work units (SKPD) of Sleman Regency and Bantul Regency, the greater the accountability of performance in local government agencies.

In regional government, some tasks and programs must be started from properly planning, implementing, monitoring, and accountability. Thus, local governments need an internal control system to encourage the achievement of goals or targets that have been planned. The internal control system can also encourage top-level government officials to supervise and control the performance of each government apparatus so that all government components can continuously improve performance in achieving regional government goals and targets and can be accounted for by various interested parties.

\subsection{The Influence of Participation in Budgeting on the Performance Accountability of Local Government Agencies}

In the research results on the third hypothesis (H3), it can be seen that budgetary participation did not affect the accountability of the performance of local government agencies, with a significance value of $0.329>$ alpha $(\alpha=0.05)$. The results of this test signify that the participation in budgeting carried out by each apparatus in local government did not increase performance accountability in local government agencies.

No effect on budgetary participation was based on government agency work units (SKPD) of Sleman Regency 
and Bantul Regency not including all top-level apparatus to lower-level apparatus in budget preparation so that government officials who did not participate in budget preparation lacked the awareness to account for the budget. Lack of awareness in being responsible for the budget could affect performance, to be ineffective, efficient, and economical. Every government apparatus must always report the results of its performance and be accountable to interested parties to improve the performance of local government agencies.

\subsection{The Influence of Accounting Control on Performance Accountability of Local Government Agencies}

In the research results on the third hypothesis (H4), it can be seen that accounting control had a positive effect on the accountability of the performance of local government agencies, with a significance value of $0.000>(\alpha=0.05)$. The results of this test indicate that the higher the accounting control in the regional apparatus work units (SKPD) of Sleman and Bantul Regencies, the greater the accountability of performance in local government agencies. The significant influence of accounting control on performance accountability of local government agencies was because each apparatus in local government organizations carried out tasks and programs following effective, efficient, and economical performance indicators to increase the accountability of local government agencies' performance. In local government, all tasks and programs that have been planned must be implemented and accounted for according to what is in the field. Each government apparatus is also responsible for securing assets and recording all financial transactions to add information in making decisions that can be accounted for by interested parties. Thus, accounting control carried out by all apparatus in local government organizations can assist in increasing the accountability of existing performance in local government agencies.

\section{CONCLUSION}

This study aims to empirically prove the role of human resource competence, internal control systems, budgetary participation, and accounting control on the local government agencies' performance accountability (empirical studies on SKPD in Sleman and Bantul Regencies). The sample in this study was 25 SKPD of Sleman Regency and Bantul Regency Governments in the Special Region of Yogyakarta, which included: Regional Secretariat, Service, Agency, and Office. This study used a purposive sampling technique, with the number of questionnaires processed of 73 questionnaires, so the following are the results of this study:

1. Human resource competence did not affect the performance accountability of local government agencies.

2. The internal control system had a significant positive effect on the performance accountability of local government agencies.

3. Participation in budgeting did not affect the performance accountability of local government agencies.
4. Accounting control had a significant positive effect on the performance accountability of local government agencies.

\section{LIMITATION AND FUTURE RESEARCH}

In this study, there are several limitations:

1. The distribution of questionnaires was disrupted by the COVID-19 outbreak since some questionnaire collection points were closed.

2. In this study, the data collection technique used a questionnaire without being equipped with interviews.

Based on the results of this study, the researchers provide suggestions for similar research in the future as follows:

1. Adding respondents, not only the regional secretariat, office, agency, and offices, and can add other regencies to get even more data

2. Further research can also add direct interviews so that filling out the questionnaire is more objective.

\section{REFERENCES}

[1] Anjarwati, M. (2012). Pengaruh Partisipasi Anggaran, Kejelasan Sasaran Anggaran, Pengendalian Akuntansi dan Sistem Pelaporan Terhadap Akuntabilitas Kinerja Instansi Pemerintah Daerah dengan Komitmen Organisasi sebagai Variabel Pemodaerai. Jurnal Akuntansi dan Investasi, 13(1), 15-27. https://doi.org/ISSN 2252-6765

[2] Antara News. Pemkab Sleman raih predikat "A" implementasi SAKIP (2020). Diambil dari https://www.antaranews.com/berita/1315826/pemkabsleman-raih-predikat-a-implementasi-sakip

[3] Aprilianti, D., Wulan, M., \& Kurniawan, H. (2020). Pengaruh Kejelasan Sasaran Anggaran, Pengendalian Internal, dan Sistem Pelaporan Terhadap Akuntabilitas Kinerja Instansi Pemerintah di Kecamatan Wilayah Jakarta Selatan. Jurnal Ilmiah Akuntansi dan Keuangan, 9(2), 150-159. https://doi.org/10.32639/jiak.v9i2.454

[4] Arifin, W. B. (2012). Pengaruh Partisipasi Anggaran, Kejelasan Sasaran Anggaran, Pengendalian Akuntansi Dan Sistem Pelaporan Terhadap Akuntabilitas Kinerja Instansi Pemerintah Daerah Dengan Komitmen Organisasi Sebagai Variabel Pemoderasi. Jurnal Akuntansi dan Investasi, 13(1), 15-27.

[5] Cahyani, N. M. M., \& Utama, I. M. K. (2015). Pengaruh Kejelasan Sasaran Anggaran,Pengendalian Akuntansi Dan Sistem Pelaporan Pada Akuntabilitas Kinerja. EJurnal Akuntansi, 10(3), 825-840.

[6] Darma, D. A. (2019). Pengaruh Implementasi Standar Akuntansi Pemerintah Berbasis Akrual dan Pengawasan Kualitas Laporan Keuangan Terhadap Akuntabilitas Kinerja Instansi Pemerintah Pada Dinas Lingkungan Hidup, Dinas Kehutanan, dan Dinas Kebudayaan dan 
Pariwisata pemerintah Pro. Jurnal Akuntansi Bisnis dan Publik, 9(2), 30-43.

[7] Davis, J. H. (1997). Toward A Stewardship Theory Of Management. Academy of management review, 22(1), 20-47.

[8] Elizar, E., \& Tanjung, H. (2018). Pengaruh Pelatihan, Kompetensi, Lingkungan Kerja terhadap Kinerja Pegawai. Maneggio: Jurnal Ilmiah Magister Manajemen, 1(1), 46-58. https://doi.org/10.30596/maneggio.v1i1.2239

[9] Fathia, N., Yusralaini, P. :, \& Anggraini, L. (2017). Pengaruh Penerapan Sistem Akuntansi Pemerintah Daerah, Penerapan Anggaran Berbasis Kinerja, Kejelasan Sasaran Anggaran, Sistem Pelaporan Kinerja dan Pengendalian Akuntansi Terhadap Akuntabilitas Kinerja Instansi Pemeritah (AKIP) (Study Kasus SKPD di Provi. JOM Fekon, 4(1), 670-685.

[10]Hafiz, M. (2017). Pengaruh Kompetensi Aparatur Pemerintaha, Ketaatan Pada Peraturan Perundangan dan Kejelasan Sasaran Anggaran Terhadap Akuntabilitas Kinerja Instansi Pemerintah Dengan Komitmen Organisasi dan Kinerja Manajerial Sebagai Variabel Moderating (Studi Empiris Pa. JOM Fekon, 4(1), 528542.

[11] Hari Setyawan. (2017). Pengaruh Kejelasan Sasaran Anggaran, Pengendalian Akuntansi dan Ketaatan Pada Peraturan Perundangan Terhadap Akuntabilitas Kinerja Instansi Pemerintah Dengan Kinerja Manajerial Sebagai Variabel Moderating. JOM Fekon, 4(1), 251-264.

[12] Hidayattullah, A., \& Herdjiono, I. (2015). Pengaruh Kejelasan Sasaran Anggaran, Pengendalian Akuntansi, Sistem Pelaporan Terhadap Akuntabilitas Kinerja SKPD di Merauke. Prosiding Seminar Nasional Multi Disiplin Ilmu, 978-979.

[13] Irvan, N., Mus, A. R., Su'un, M., \& Sufri, M. (2017). Effect of Human Resource Competencies, Information Technology and Internal Control Systems on Good Governance and Local Government Financial Management Performance. IRA-International Journal of Management \& Social Sciences (ISSN 2455-2267), 8(1), 31. https://doi.org/10.21013/jmss.v8.n1.p4

[14] Kaltsum, U., \& Rohman, A. (2012). Pengaruh Kejelasan Sasaran Anggaran Terhadap Akuntabilitas Kinerja Instansi Pemerintah Melalui Sistem Pengendalian Intern Sebagai Variabel Intervening (Studi Empiris pada Satuan Kerja Perangkat Daerah Kota Salatiga) Ummu. ejurnal undip, 3(1), 215-228.

[15] Kementerian Pemberdayaan Aparatur Negara dan Reformasi Birokrasi. (n.d.). Sistem Akuntabilitas Kinerja Instansi Pemerintah (SAKIP). menpan.go.id. Diambil dari https://www.menpan.go.id/site/reformasibirokrasi/permasalahan-dan-tindak-lanjut-ke-depan

[16] Mamuaja, B. (2016). Analisis Efektivitas Penerapan
Sistem Pengendalian Intern Terhadap Kinerja Instansi Pemerintah di Dinas Pendapatan Kota Manado. Jurnal EMBA, 4(1), 165-171.

[17] Manullang, S. B., \& Abdullah, S. (2019). Pengaruh Pengendalian Internal, Kejelasan Anggaran dan Pergantian Kepala SKPD terhadap Akuntabilitas Kinerja. Jurnal Ilmiah Mahasiswa Ekonomi Akuntansi (JIMEKA), 4(1), 62-73.

[18] Mikoshi, M. S. (2020). Pengaruh Kejelasan Sasaran Anggaran , Pengendalian Akuntansi dan Sistem Pelaporan Terhadap Akuntabilitas Kinerja ( Studi Empiris Koni Se Sumatera Barat ). jurnal of economics and business, 4(1), 192-199. https://doi.org/10.33087/ekonomis.v4i1.116

[19] Nazaruddin, I., \& Basuki, A. T. (2015). Analisis statistik dengan SPSS. Yogyakarta: Danisa Media.

[20] Nazaruddin, \& Setyawan, H. (2012). Pengaruh partisipasi penyusunan anggaran terhadap kinerja aparat pemerintah daerah dengan budaya organisasi, komitmen organisasi, motivasi, desentralisasi, dan job relevant information sebagai variabel moderasi. Jurnal Akuntansi dan Investasi, 12(2), 197-207.

[21] Peraturan Presiden nomer 29 tahun 2014. (2014). Peraturan Presiden Republik Indonesia Nomer 29 Tahun 2014 Tentang Sistem Akuntabilitas Kinerja Instansi Pemerintaha.

[22] Pratama, R., Agustin, H., \& Taqwa, S. (2019). Pengaruh Kejelasan Sasaran Anggaran, Pengendalian Akuntansi, Sistem Pelaporan, Dan Desentralisasi Terhadap Akuntabilitas Kinerja Instansi Pemerintah (Skpd Bengkalis). Jurnal Online Mahasiswa Fakultas Ekonomi Universitas Riau, 3(1), 1123-1136.

[23] Pratiwi, E. (2014). Pengaruh Partisipasi Penyusunan Anggaran dan Sistem Pelaporan Terhadap Akuntabilitas Sekolah SMP dan SMA Negeri Kota Semarang (Studi Pada SMP dan SMA Negeri Kota Semarang). Journal of Chemical Information and Modeling, 53(9), 1689-1699. https://doi.org/10.1017/CBO9781107415324.004

[24] Pratolo, S. (2008). Transparansi Dan Akuntabilitas Tata Kelola Pemerintahan Daerah Dalam Hubungannya Dengan Perwujudan Keadilan Dan Kinerja Pemerintah Daerah: Sudut Pandang Aparatur Dan Masyarakat Di Era Otonomi Daerah. Jurnal Akuntansi dan Investas, 9(2), $108-124$.

[25] Pratolo, S., Jatmiko, B., \& Anwar, M. (2016). "Financial Statement Public Sectors Berbasis WEB-ICT: Pola Pemetaan Laporan Keuangan Melalui WEB-ICT Untuk Mewujudkan Transparansi dan Akuntabilitas (Studi Kasus SKPD Kabupaten Bantul). Reposiitory Universitas Muhammadiyah Yogyakarta.

[26] Precelina, D. D., \& Wuryani, E. (2019). Pengaruh Kejelasan Sasaran Anggaran, Pengendalian Akuntansi, Dan Sistem Pelaporan Terhadap Akuntabilitas Kinerja 
Instansi Pemerintah Kabupaten Jombang. Jurnal Akuntansi AKUNESA, 7(3), 1-10.

[27] Putra, A. P. (2018). Determinan akuntabilitas kinerja pemerintah di Kabupaten Lombok Barat. Jurnal Ekonomi dan Keuangan, 2(2), 271-290. https://doi.org/10.24034/j25485024.y2018.v2.i2.3942

[28] Putri, E. M. N. (2015). Pengaruh Kompetensi Aparatur Pemerintah Derah, Penerapan Akuntabilitas Keuangan, Pemanfaatan Teknologi Informasi, dan Ketaatan Pada Peraturan Perundangan Terhadap Akuntabilitas Kinerja Instansi H (AKIP) (Empirical Study On the regional work units Pekanbar. JOM Fekom, 2(2), 1-15.

[29] Radar Jogja. SAKIP Pemkab Bantul Raih Predikat A (2020). Diambil dari https://radarjogja.jawapos.com/2020/02/26/sakippemkab-bantul-raih-predikat-a/

[30] Raharjo, E. (2007). Teori Agensi dan Teori Stewarship dalam Perspektif Akuntansi. fokus ekonomi, 2(1), 37-46.

[31] Razi, R. F. (2017). Pengaruh Ketaatan Terhadap Peraturan Perundangan, Pemanfaatan Teknologi Informasi, Pengendalian Akuntansi dan Kompetensi Aparatur Pemerintah Daerah Terhadap Akuntabilitas Kinerja Instansi Pemerintah (AKIP) (Studi Empiris Pada Satuan Kerja Perangkat Daerah. JOM Fekom, 4(1), 1268-1281.

[32] Reynaldhie, muhammad try, \& Mahmudi. (2016). Pengaruh Gaya Kepemimpinan, Komitmen Organisasi, Budaya Organisasi, Lingkungan (hal. 2-23).

[33] Soeksin, S. D., Friandi, S. Z., \& Rifai, D. (2020). Pengaruh Kejelasan Sasaran Anggaran dan Partisipasi Penyusunan Anggaran Terhadap Akuntabilitas Kinerja Instansi Pemerintah Kota Tarakan. JAMAN, 1(1), 40-47.

[34] Sudiarianti, N. M., Ulupui, I. G. K. A., \& Budiasi, I. G. A. (2015). Pengaruh kompetensi sumber daya manusia pada penerapan sistem pengendalian intern pemerintah dan standar akuntansi pemerintah serta implikasinya pada kualitas laporan keuangan pemerintah daerah. In Simposium Nasional Akuntansi (hal. 1-25). Bali.

[35] Suryani, A. I. (2018). Flypaper Effect Pada Pendapatan Asli Daerah (PAD) dan Dana Alokasi Umum (DAU) Terhadap Belanja Daerah (Studi Pada Pemerintahan Kabupaten/Kota di Provinsi Jawa Timur, Jawa Tengah dan Jawa Barat Periode 2011-2013). Journal of Accounting $\quad$ Science, $2(2), \quad 165$. https://doi.org/10.21070/jas.v2i2.2098

[36] Susanti, M. (2017). Pengaruh Kejelasan Tujuan Anggaran dan Partisipasi Penyusunan Anggaran Terhadap Akuntabilitas Kinerja Instansi Pemerintah( Studi Empiris Pada Instansi Pemerintah Kota Bengkulu ). Jurnl Management Insight, 12(2), 7788.

[37] Triyulianto, T. (2018). An Evaluation of a Government Performance Accountability System Indonesian District
Governments 2010. Jurnal trasparasi, 1(1), 85-100.

[38] UU Nomer 32 Tahun 2004. (2004). Undang - Undang Republik Indonesia Nomor 32 Tahun 2004 Tentang Pemerintah Daerah.

[39] Wardhana, G. A. S., Rasmini, N. K., \& Astika, I. B. P. (2015). Instansi Pemerintah Dengan Komitmen Organisasi. E-journal Ekonomi dan Bisnis, 4(9), 571598.

[40] Widyatama, A., Novita, L., \& Diarespati, D. (2017). Pengaruh Kompetensi Dan Sistem Pengendalian Internal Terhadap Akuntabilitas Pemerintah Desa Dalam Mengelola Alokasi Dana Desa (Add). Berkala Akuntansi dan Keuangan Indonesia, 2(2), 1-20. https://doi.org/10.20473/baki.v2i2.4762

[41] Zakiyudin, M. A., \& Suyanto. (2015). Kejelasan Sasaran Anggaran , Pengendalian Akuntansi, Sistem Pelaporan dan Akuntabilitas Kinerja Instansi Pemerintah pada Inspektorat Jenderal Kementerian Agama RI. Jurnal Riset Akuntansi dan Perpajakan JRAP, 2(1), 89-96.

[42]Zirman, Darlis, E., \& Rozi, R. M. (2010). Pengaruh Kompetensi Aparatur Pemerintah Daerah, Penerapan Akuntabilitas Keuangan, Motivasi Kerja, Dan Ketaatan Pada Peraturan Perundangan Terhadap Akuntabilitas Kinerja Instansi Pemerintah. Jurnal Ekonomi Universitas Riau, 18(01), 8780. 